\title{
Investigation of in-vitro biological activities of silver nanoparticles synthesized by green synthesis method using wild edible mushroom Macrolepiota procera*
} Yenilebilir mantar Macrolepiota procera kullanılarak yeşil sentez yöntemiyle sentezlenen gümüş nanopartiküllerinin in-vitro biyolojik aktivitelerinin araştırılması

Serpil Gonca

iPhD., University of Mersin, Faculty of Pharmacy, Department of Pharmaceutical Microbiology https://orcid.org/0000-0002-8544-1184

\begin{abstract}
Aim: Mushrooms known that to be used in traditional treatment among the people as they can generate a large diversity of secondary metabolites. In the present study, it was aimed to synthesized silver nanoparticles (AgNPs) mediated Macrolepiota procera, which is known to have diverse biological activities such as anticancer, antioxidant, antimicrobial in previous studies, and to investigated various in-vitro biological activities of these AgNPs.

Materials and Methods: Synthesized Mp-AgNPs were characterized using transmission electron microscopy (TEM). Various biological activities including antimicrobial, biofilm inhibition and cell viability inhibition, DNA cleavage, DPPH activity of synthesized AgNPs were investigated in-vitro.

Results: The highest DPPH scavenging activity of Mp-AgNPs was found as $92.72 \%$, at $200 \mathrm{mg} / \mathrm{L}$ concentration. Mp-AgNPs caused single strain break in the E. coli pBR322 plasmid DNA. Mp-AgNPs showed moderate antimicrobial activity against tested microorganisms. Furthermore, the biofilm inhibition activity of Mp-AgNPs toward P. aeruginosa and S. aureus was $65.80 \%$ and $72.60 \%$ at $200 \mathrm{mg} / \mathrm{L}$, respectively. Inhibition activity of $E$. coli cell viability of Mp-AgNPs was found as $99.99 \%$ at $500 \mathrm{mg} / \mathrm{L}$.

Conclusion: From the findings obtained in the study, the use of $M$. procera in the AgNPs synthesis it is important private regard due to its low cost, eco-friendly, high yield and non-toxicity human health. In addition, newly synthesized AgNPs can be used effectively for different applications after further studies.
\end{abstract}

Keywords: Nanoparticles, Antioxidant, Antimicrobial activity, Biofilm inhibition, Microbial cell viability.

Öz

Amaç: Mantarlar, çok çeşitli sekonder metabolitler üretebilmeleri nedeniyle halk arasında geleneksel tedavide kullanıldıkları bilinmektedir. Bu çalışmada, daha önce yapılan çalışmalarda anti-kanser, antioksidan, antimikrobiyal gibi çeşitli biyolojik aktiviteleri olduğu bildirilen gümüş nanopartiküllerin (AgNP'ler) Macrolepiota procera aracılı sentezlenmesi ve bu AgNP'lerin çeşitli in-vitro biyolojik aktivitelerinin araştırılması amaçlanmıştır.

Yöntem: Sentezlenen Mp-AgNP'ler, transmisyon elektron mikroskobu (TEM) kullanılarak karakterize edildi. Sentezlenen AgNP'lerin antimikrobiyal, biyofilm inhibisyonu ve hücre canlılı̆ı inhibisyonu, DNA bölünmesi, DPPH aktivitesi gibi çeşitli biyolojik aktiviteleri invitro olarak incelenmiştir.

Bulgular: Mp-AgNP'lerin en yüksek DPPH süpürme aktivitesi $200 \mathrm{mg} / \mathrm{L}$ konsantrasyonda $\% 92.72$ olarak tespit edildi. Mp-AgNP'ler, $E$. coli pBR322 plazmid DNA'sında tek zincir kırığına neden oldu. Mp-AgNP'ler, test edilen mikroorganizmalara karşı orta düzeyde antimikrobiyal aktivite gösterdi. Ayrıca, Mp-AgNP'lerin P. aeruginosa ve S. aureus'a karşı biyofilm inhibisyon aktivitesi, $200 \mathrm{mg} / \mathrm{L}$ 'de sırasıyla \%65.80 ve \%72.60 idi. Mp-AgNP'lerin E. coli hücre canlıı̆̆ının inhibisyon aktivitesi, 500 mg/L'de \%99,99 olarak tespit edildi. Sonuç: Çalışmada elde edilen bulgulara göre, M. procera'nın AgNP sentezinde kullanılması, düşük maliyetli, çevre dostu, yüksek verime sahip olması ve insan sağlığına toksik olmaması nedeniyle özel önem taşımaktadır. Ayrıca yeni sentezlenen AgNP'ler yapılacak ileri çalışmalardan sonra farklı uygulamalar için etkin bir şekilde kullanılabilirler.

Anahtar Kelimeler: Nanopartikül, Antioksidan, Antimikrobiyal aktivite, Biyofilm inhibisyonu, Mikrobiyal hücre canlılı̆ı.

"Mersin Üniversitesi Tıp Fakültesi Lokman Hekim Tıp Tarihi ve Folklorik Tıp Dergisi, 2022; 12 (1): 198-208

DOI: 10.31020/mutftd.1031151

e-ISSN: 1309-8004, ISSN 1309-761X

Geliş Tarihi - Received: 01 December 2021; Kabul Tarihi - Accepted: 27 December 2021

Iletişim - Correspondence Author: Serpil Gonca <serpilgonca@mersin.edu.tr> 


\section{Introduction}

Nanotechnology is a scientific, technological and engineering branch that has become a major field worldwide in recent years to study the application of tiny things between 1-100 $\mathrm{nm}$. Nanotechnology is a branch the study of nanoscience which indicates various implementation in many area including biology, physics, and chemistry. ${ }^{1}$ In recent years, studies on metallic NPs, which are an indispensable part of nanotechnology, are progressing rapidly. NPs show the significant physical and chemical features when compared to their bulk form, which is referred to their high surface area/volume ratio as well as electronic features. ${ }^{2}$

Nanoparticles are mainly synthesized via three approaches: physical method, chemical method, and biological method. ${ }^{3}$ An alternative method is needed due to the use of toxic and very precious chemicals in addition to high temperature in the synthesis phase of NPs by chemical and physical methods. ${ }^{4}$ The green synthesis method of NPs worths special regard owing to its low cost, eco-friendly, high yield and nontoxicity. ${ }^{3,4}$

Among the metal NPs, AgNPs one of the most notable nanomaterial specially due to their biological features. In numerous studies by different researchers demonstrated the antibacterial, antifungal, anticancer, antimutagenic action, antiviral, antioxidant, and the wound healing properties of AgNPs. ${ }^{5-11}$

For thousands of years, people have used mushrooms for the treatment of various diseases. ${ }^{12}$ Moreover, though mushrooms are regarded as nutrients for the first time, it has been detected by many studies that they have medicinal features including antioxidant, antimicrobial, immune modulation and antitumor properties so in folkloric-medicine some of them have been used as drug. ${ }^{12-14}$ It has been reported in studies that the medicinal properties of edible mushrooms have been attributed to the high polysaccharides they contain, especially $\beta$-glucans. ${ }^{12}$ In addition, according to research, in relation to $\beta$-glucans found in edible mushrooms are believed to strengthen the immune system by influencing cellular activities and secondary production of chemical compounds, and to repair diseases and to restore damaged cellular immunity caused by radiation and chemotherapy..$^{13}$ Also, mushrooms can be utilized for therapeutic aims due to they can generate various secondary metabolites including steroids, terpenoids, organic acids, phenolic compounds, and alkaloids. ${ }^{15}$

M. procera includes lepiotan, mannitol, trehalose, glucose, glycerol, and almost 20 amino acids. Since $M$. procera has been noticed that to indicate antitumor activity to human body and show an antimicrobial activity, the fruiting bodies have been broadly utilized to fabrication conventional foods and medicine. ${ }^{14}$

Considering the above information, in our study, we used Macrolepiota procera, an edible fungus species, as a stabilizing and reducing agent in the production of AgNPs. The synthesized NPs were characterized by TEM. Moreover, we aimed to investigate various in-vitro biological activities including antimicrobial, antioxidant, and DNA cleavage activities of synthesized AgNPs.

\section{Material and Methods}

\section{Materials}

Silver nitrate $\left(\mathrm{AgNO}_{3}\right)$ to be used in the synthesis of silver nanoparticle was obtained from Merck. All used chemicals were of analytical reagent grade. The distilled water (DW) used in the study was obtained from Millipore Direct-Q 3 UV. 


\section{Extraction procedure}

Washed mushroom material was dried in oven set at $25^{\circ} \mathrm{C}$ for five days at laboratory condition and produced a fine powder with an electric grinder. Later, $5 \mathrm{~g}$ of powdered dried mushroom Macrolepiota procera was soaked in $100 \mathrm{~mL}$ of methanol at room temperature for $48 \mathrm{~h}$. It was then filtered using by Whatman filter paper. Then, they were kept in an oven set at $65^{\circ} \mathrm{C}$ for three days to remove methanol from the filtered samples.

\section{Green synthesis of AgNPs}

To obtain AgNPs using Macrolepiota procera metanol extract, silver nitrate solution was prepared at 10 $\mathrm{mM} .{ }^{16}$ Then, $300 \mathrm{~mL}$ of the prepared solutions was added to $100 \mathrm{~mL}$ of Macrolepiota procera metanol extract and left to react at $70^{\circ} \mathrm{C}$ overnight. Finally, the prepared AgNPs were washed a few times with distilled water and left to dry in an oven set at $80^{\circ} \mathrm{C}$ for $24 \mathrm{~h}$.

\section{Nanoparticles characterization methods}

The morphological and topographical analysis of synthesized MP-AgNPs were performed via TEM. The information about the device used for characterization was Jeol JEM-1011.

\section{DPPH activity}

The DPPH scavenging activity of Mp-AgNPs was studied as reported by Ağırtaş with some modifications. ${ }^{17}$ Briefly, $250 \mu \mathrm{L} \mathrm{AgNPs}$ in concentrations range of 12.5-100 mg/L $(12.5,25,50,100$, and $200 \mathrm{mg} / \mathrm{L})$ and standards (Ascorbic acid and Trolox) were taken and $1 \mathrm{~mL}$ of newly prepared $1 \mathrm{mM}$ DPPH methanol solution was added. Later, this mixture was vortexed thoroughly and incubated in dark place for $30 \mathrm{~min}$. After $30 \mathrm{~min}$, the DPPH free radical scavenging activity was detected at $517 \mathrm{~nm}$ by a spectrophotometer. The radical scavenging activity was calculated using the following equation. (1):

Capacity $(\%)=\left(\frac{A b s(\text { control })-A b s(\text { sample })}{A b s(\text { control })}\right) \times 100$

\section{DNA cleavage ability}

DNA cleavage study was realized to test the effect of AgNPs synthesized from Macrolepiota procera on DNA, and E. coli pBR 322 plasmid DNA was used as a model target substance for this aim. The experiment was based on the principle of treating NPs at varied concentrations range from $50-200 \mathrm{mg} / \mathrm{L}$ with plasmid DNA for $45 \mathrm{~min}$ at $37^{\circ} \mathrm{C}$. Then, to observe the effect of newly synthesized Mp-AgNPs on DNA, the reaction mixture was loaded to the gel and agarose gel electrophoresis was performed at $90 \mathrm{~min}, 80 \mathrm{~V}$, and $120 \mathrm{~mA}$.

\section{Antimicrobial activity}

Minimum inhibitory concentration (MIC) of synthesized AgNP was researched against $\mathrm{Gr}(+)$, $\mathrm{Gr}(-)$ and fungal strain using serial dilution method. The strains used for this purpose were as follows; Staphylococcus aureus, Enterococcus faecalis, Enterococcus hirae, Escherichia coli, Legionella pneumophila subsp. pneumophila, and Pseudomonas aeruginosa, Candida tropicalis, and Candida parapisilosis. The microorganisms used in our research were grown overnight before serial dilution. For the work, two-fold serial dilutions of Mp-AgNP were made. Then, the microorganisms we used in our study were inoculated to the microplate wells. Subsequent plates were kept in the oven for incubation at $37^{\circ} \mathrm{C}$ for $24 \mathrm{~h}$. After $24 \mathrm{~h}$, antimicrobial activity was evaluated with MIC, described as the lowest concentration that inhibits microbial growth. 


\section{Bacterial cell viability activity}

E. coli bacteria was used to microbial cell viability procedure. First, the bacterium was inoculated into Nutrient Broth (NB) medium. It was then incubated at $37^{\circ} \mathrm{C}$ on a shaker for $24 \mathrm{~h}$. When the incubation time was over, the growth medium was centrifuged to collect $E$. coli cells. Afterwards, sterile saline solution was added to clean the bacterial pellet and with centrifugation was washed several times. When washing step was finished, E. coli strains were suspended with sterile $\mathrm{NaCl}$. This prepared suspension was used in the cell viability method afterwards. E. coli was mixed homogenously with different concentration (range from 125$500 \mathrm{mg} / \mathrm{L}$ ) of Mp-AgNPs for $60 \mathrm{~min}$ at $37^{\circ} \mathrm{C}$. Later $60 \mathrm{~min}$, it was diluted in different ratios and inoculated on NB agar medium and incubated at $37^{\circ} \mathrm{C}$ for 24 hours. The same procedure was also studied with the control group that did not contain green synthesized AgNPs. Eventually, microbial cell viability was calculated by counting colonies and using equation (2) given below.

Cell viability (\%) $=\left(A_{\text {control }}-A_{\text {sample }} / A_{\text {control }}\right) \times 100$

\section{Biofilm inhibition activity}

The two microorganisms were selected $\operatorname{Gr}(+)$ and $\operatorname{Gr}(-)$ ( $P$. aeruginosa and $S$. aureus), to reveal the biofilm inhibition activity of newly synthesized AgNPs. Well plates containing different concentrations of AgNPs were inoculated with $P$. aeruginosa and $S$. aureus and left to incubate at $37^{\circ} \mathrm{C}$ for $72 \mathrm{~h}$. After $72 \mathrm{~h}$, the well plates were emptied slowly and washed twice with distilled water. The plates were kept in an oven set at $70^{\circ} \mathrm{C}$ for $20 \mathrm{~min}$ to dry. Then, crystal violet (CV) dye was added to the wells and left for $30 \mathrm{~min}$. At the end of the time, the CV was poured and the contents of the wells were gently washed two times. Subsequently, ethanol was then added. It was waited for $15 \mathrm{~min}$ for the absorbed CV to recover the CV. The biofilm inhibition activity was defined with spectrophotometer at $595 \mathrm{~nm}$. Wells with only bacteria were considered as positive control and the activity of biofilm inhibition was calculated using the equation (3) given below.

Biofilm Inhibition $(\%)=\left(\frac{A b s(\text { control })-\text { Abs }(\text { sample })}{A b s(\text { control })}\right) \times 100$

\section{Result and Discussion}

\section{Nanoparticles characterization}

TEM was applied to detect Mp-AgNPs' surface morphology. It was determined that the particle size of the Mp-AgNPs obtained as a result of TEM was in the range of 22.67-25.99 $\mathrm{nm}$. Moreover, based on the data obtained from the TEM images, the synthesized AgNPs were in spherical morphology (Figure 1). 

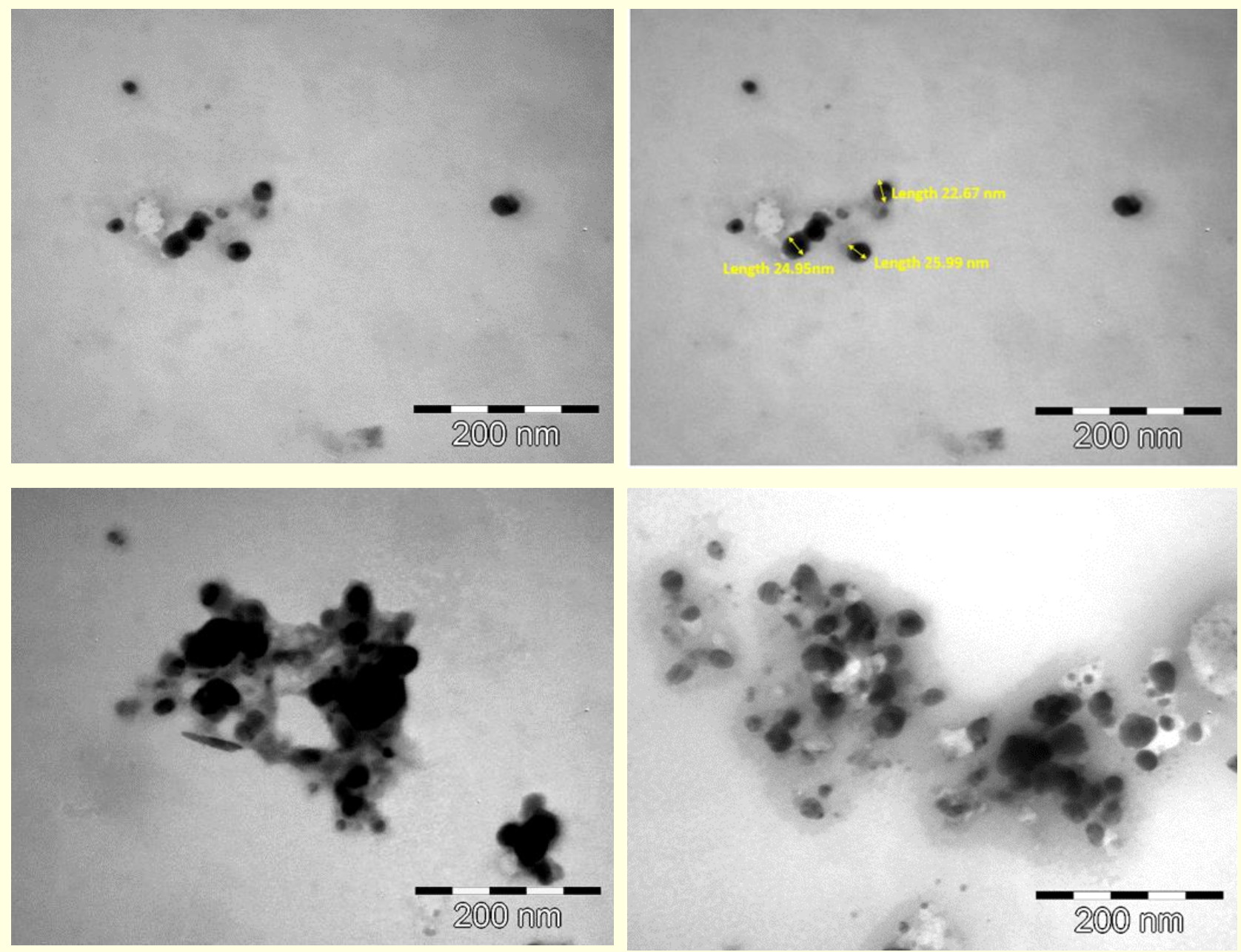

Figure 1. Characterization of AgNPs - TEM image

\section{DPPH activity}

An unbalance between the antioxidant and pro-oxidants results in formation of oxidative stress in biological systems with reduce in antioxidant enzymes causing to harm of crucial biomolecules and other cellular components. ${ }^{18}$ In addition, ROS, which is released as a result of oxidative stress, contributes to the formation of various diseases including cardiovascular and neurodegenerative diseases. Antioxidants play a protective role in diseases caused by oxidative stress. ${ }^{19}$ Therefore, it is important to discover new products that are natural and environmentally friendly with antioxidant properties. In the study, the antioxidant activity of AgNPs synthesized from Macrolepiota procera was investigated by DPPH method. The results of the study are presented in Figure 2. As seen in the Figure 2, DPPH activity increased with the increase in concentration as mentioned by other researchers. ${ }^{20,21}$ In addition, the DPPH scavenging effect of Mp-AgNPs was compared with Ascorbic acid and Trolox, which were used as standard. According to the results of the study, the DPPH scavenging activity of Mp-AgNPs was found to be $38.64 \%, 49.30 \%, 56.83 \%, 81.80 \%$, and $92.72 \%$ at $12.5 \mathrm{mg} / \mathrm{L}$, $25 \mathrm{mg} / \mathrm{L}, 50 \mathrm{mg} / \mathrm{L}, 100 \mathrm{mg} / \mathrm{L}$, and $200 \mathrm{mg} / \mathrm{L}$ concentrations, respectively. As the concentration increased from $12.5 \mathrm{mg} / \mathrm{L}$ to $200 \mathrm{mg} / \mathrm{L}$, the DPPH scavenging activity of Ascorbic acid, Trolox and Mp-AgNPs also increased from $84.12 \%$ to $100 \%$, from $86.39 \%$ to $100 \%$ and from $38.64 \%$ to $92.72 \%$, respectively. The efficient free radical scavenging activities of the newly synthesized AgNPs could be due to the combined impact of both AgNPs as well as of the bioactive compounds present in the Macrolepiota procera extract. In previous studies with AgNPs, it has been reported that AgNP had antioxidant activity. A study, Palanisamy synthesized silver nanoparticles using Sargassum polycystum and evaluated its in-vitro antioxidant activity via DPPH method. 
They found that AgNPs exhibited the high DPPH radical inhibition with $78.2 \%$ at concentration of 500 $\mu \mathrm{g} / \mathrm{mL} .{ }^{22}$ Ravichandran reported that they synthesized AgNPs using Atrocarpus altilis and DPPH radical scavenging activities was $79.79 \%$ at $100 \mu \mathrm{g} / \mathrm{mL}$ concentration. ${ }^{23}$ This results are lower than the results of present study. Wang synthesized silver NPs using Psidium guajava leaf aqueous extract and it was determined that the DPPH scavenging activities was found $83.59 \%$ at $100 \mu \mathrm{g} / \mathrm{mL}$ concentration which was compatible with our results. ${ }^{24}$ In another study conducted by Khorrami, the newly synthesized AgNPs inhibited $77 \%$ of DPPH free radicals. ${ }^{25} \mathrm{As}$ a result, the antioxidant activity results of the synthesized Mp-AgNPs are quite good and the usage of synthesized Mp-AgNPs as an antioxidant agent will open new opportunities for the improvement of medical treatment after further studies.

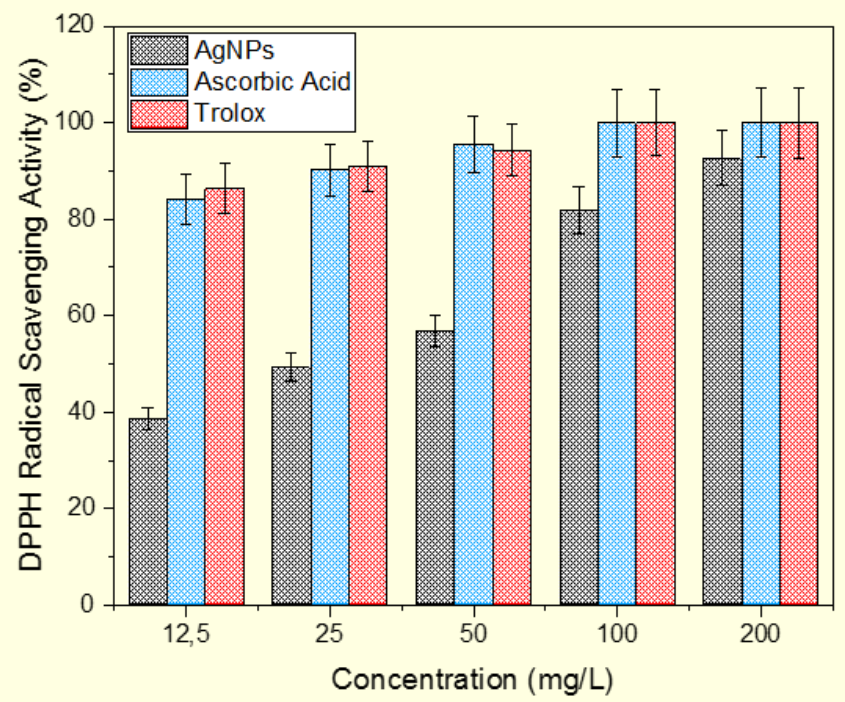

Figure 2. DPPH scavenging ability

\section{DNA cleavage activity}

In the presented study, the effect of Macrolepiota procera mediated silver nanoparticles on DNA was also examined by the agarose gel electrophoresis method. DNA cleavage activity results are shown in Figure 3 Under normal conditions, E. coli plasmid DNA is in circular form and is observed as Form I in the gel, as seen in line 4, and is the fastest migrating form in the gel compared to other forms. As seen in line 1, 2, and 3 a single-strand DNA breaks occurred as a result of the effect with Mp-AgNPs and a transition from Form I to Form II occurred. Different studies were done to define the DNA cleavage activity of silver nanoparticles. Mousavi-Khattat investigated the DNA cleavage activity of AgNPs synthesized by chemical and green synthesis method and ultimately used the genomic DNA extracted from $E$. coli as a target and they reported that it caused DNA damage. ${ }^{26}$ Begum synthesized AgNPs by using Ficus carica leaf extract and studied DNA cleavage activity of them using as a target extracted pure DNA from $S$. aureus. They finally reported that AgNPs exhibited DNA cleavage ability. ${ }^{27}$ Our DNA cleavage activity results showed similarity with the investigations mentioned. In the present study, DNA cleavage efficiency could be regarded as an antimicrobial mechanism for Mp-AgNPs depending upon the results acquired from DNA cleavage activity test. In the pharmaceutical industry, the DNA molecule is the most significant objective molecule in both anticancer and antimicrobial studies. Therefore, molecules that can interact straight with DNA become even more significant in pharmacology as alternative solutions. As it is known, it has been shown in studies that Macrolepiota procera has anticancer activity. ${ }^{14}$ Due to, we can say that the active compounds in the Macrolepiota procera extract will also contribute to the DNA cleavage activity of Mp-AgNPs. As a result, in 
the study, the effects of AgNPs synthesized mediated M. procera on DNA promise a future in terms of use in anticancer studies and Mp-AgNPs can be applied as DNA nuclease agents after further studies in nanomedicine.

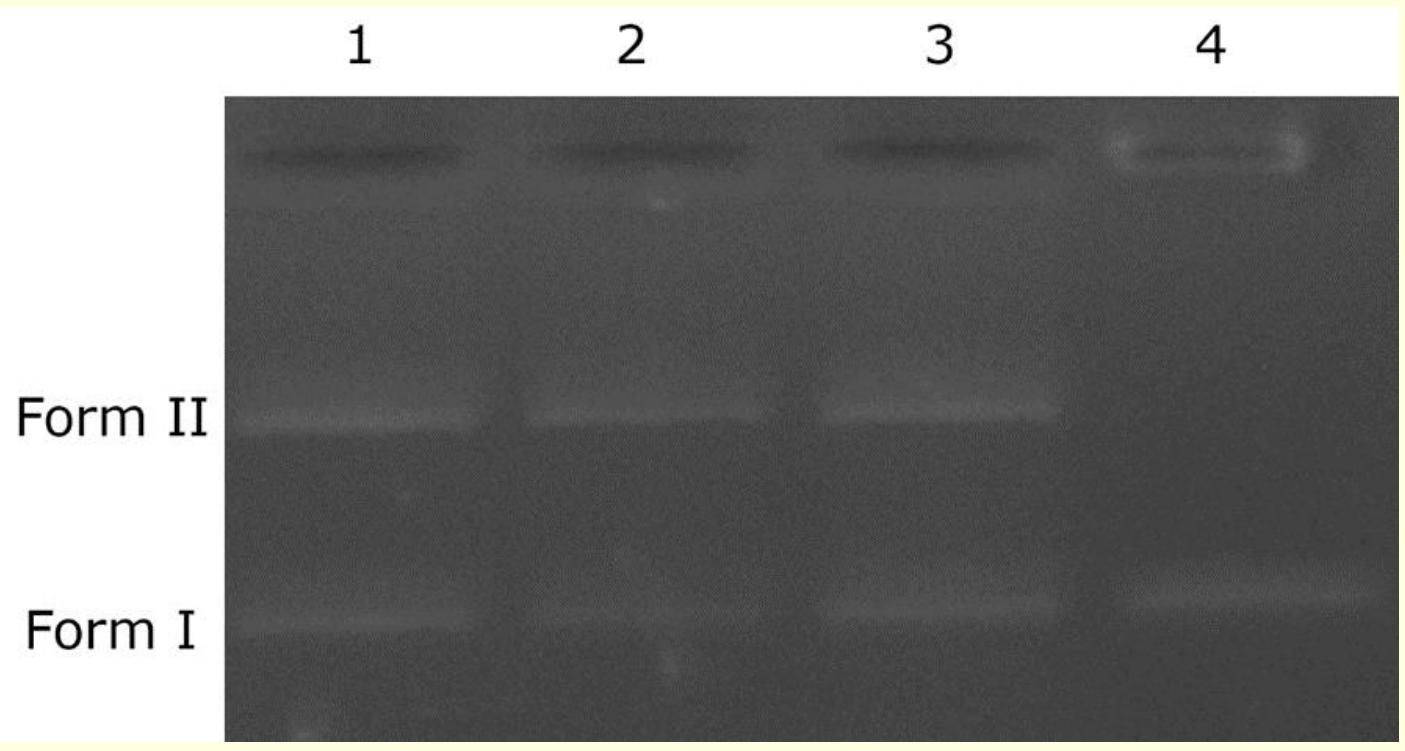

Figure 3. DNA Cleavage activity of Mp-AgNPs. Lane 1, pBR 322 DNA + 50 mg/L Mp-AgNPs; Lane 2, pBR 322 DNA + 100 mg/L of MpAgNPs; Lane 3, pBR 322 DNA + 200 mg/L Mp-AgNPs; Lane 4, pBR 322 DNA.

\section{Antimicrobial activity}

Biosynthesis methods used to obtain AgNPs are a suitable alternative to reduce the toxic effect of reagents used in chemical synthesis, which is one of the traditional methods. ${ }^{28}$ Taking this information into account, in the study the antimicrobial activity of the green synthesized Mp-AgNPs was determined using microdilution method. MIC results of the study are presented in the Table 1. As can be seen in the Table 1, the synthesized Mp-AgNPs showed antimicrobial activity against all studied microbial strains with varying degrees. Accordingly, the MIC value of Mp-AgNPs for was determined as $256 \mathrm{mg} / \mathrm{L}$ E. coli, L. pneumophila, C. tropicalis, $128 \mathrm{mg} / \mathrm{L}$ for $P$. aeruginosa, E. hirae, E. fecalis, C. parapisilosis and $64 \mathrm{mg} / \mathrm{L}$ for S. aureus. Moreover, among the strains studied, the strain most susceptible to Mp-AgNPs was $S$. aureus with a MIC value of 64 $\mathrm{mg} / \mathrm{L}$. The antibacterial activity of newly synthesized AgNPs may be attributed to the formation of oxidative stress, deterioration in replication of DNA, and also AgNPs can directly reason lysis of bacterial cell via damaging the cell membranes. ${ }^{29}$ As mentioned above, newly synthesized AgNPs had also DNA cleavage activity. This results from present study can be caused the antimicrobial activity against studied microorganisms. Antimicrobial activity of AgNPs has also been reported in previous studies. Such as; MoralesLozoya synthesized AgNPs using different parts of Morinda citrifolia and reported that silver nanoparticles demonstrated antibacterial activity toward S. aureus and E. coli. ${ }^{28}$ Sathishkumar reported that the synthesized AgNPs using Trichodesmium erythraeum showed antimicrobial activity against various clinical and drug resistant bacterial strains. ${ }^{30}$ Sangaonkar and Pawar synthesized AgNPs mediated Garcinia indica and indicated that newly synthesized AgNP displayed antibacterial activity against various $\mathrm{Gr}(+)$ and $\mathrm{Gr}(-)$ bacteria. ${ }^{31}$ Mehwish synthesized AgNPs using Moringa oleifera and demonstrated its antimicrobial activity against Gram +ve (S. aureus) and Gram -ve (E. coli, Salmonella enterica typhimurium, P. aeruginosa) bacteria. ${ }^{32}$ In conclusion, in the presented study, Mp-AgNPs showed varying degrees of antibacterial activity against the test microorganisms studied. When these results are combined with other studied parameters, it can be highlighted that the newly synthesized AgNPs can be used as an antimicrobial agent after further studies. 
Table 1. The minimum inhibition concentration (MIC) of test microorganisms

\begin{tabular}{ll}
\hline Microorganisms & Mp-AgNPs* \\
\hline E. coli & 256 \\
P. aeruginosa & 128 \\
L. pneumophila subsp. pneumophila & 256 \\
E. hirae & 128 \\
E. fecalis & 128 \\
S. aureus & 64 \\
C. parapisilosis & 128 \\
C. tropicalis & 256 \\
\hline * $\mathrm{mg} / \mathrm{L}$ &
\end{tabular}

\section{Bacterial cell viability test}

In the study, in-vitro cell viability inhibition activity of AgNPs synthesized from Macrolepiota procera by green synthesis method was also tested against $E$. coli. The results of the study are shown in Figure 4. Cell viability inhibition activity results of Mp-AgNPs at $125 \mathrm{mg} / \mathrm{L}, 250 \mathrm{mg} / \mathrm{L}$, and $500 \mathrm{mg} / \mathrm{L}$ concentrations were as follows; 94.37\%, 99.18\%, and 99.99\%, respectively. It is known that silver Np's show antimicrobial activity through different mechanisms. One of these mechanisms is the effects of AgNPs through ROS production. Under normal conditions, ROS produced in cells can be exterminated by antioxidant compounds (for example glutathione), but in the existence of AgNPs, the expression of antioxidant enzymes is braked. Thus, an increase in the amount of ROS causes some damage including reduced ATP, DNA damage, lipid peroxidation, breathing inhibition, and apoptosis-like response. ${ }^{33}$ The Mp-AgNPs showed excellent antibacterial activity against $E$. coli at all studied concentrations. Therefore, NP synthesized after further studies may find use in different fields in nanomedicine.

Compound $\quad$ Control $125 \mathrm{mg} / \mathrm{L}$

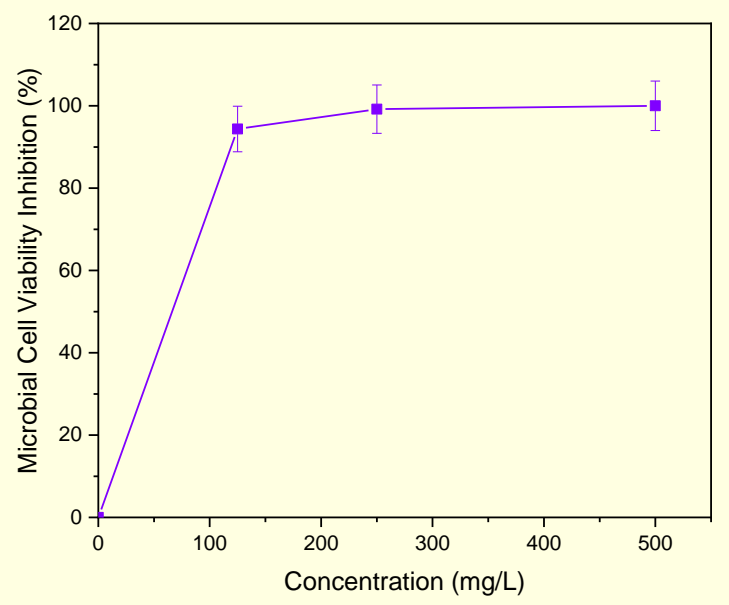

Figure 4. Microbial cell viability 


\section{Biofilm inhibition activity}

The assessment of the biofilm inhibition action of synthesized AgNPs is beneficial to establish their probable implementations in the therapy of many diseases caused by biofilm formation microorganisms. The biofilm inhibition activity of the green synthesized Mp-AgNPs was evaluated by in-vitro method against $S$. aureus and $P$. aeruginosa. The results of the study are given in Figure 5. According to these findings; biofilm inhibition activity of synthesized Mp-AgNPs was determined as $43.18 \%, 58.51 \%, 72.60 \%$ for $S$. aureus and $40.64 \%$, $48.58 \%, 65.80 \%$ for $P$. aeruginosa at $125 \mathrm{mg} / \mathrm{L}, 250 \mathrm{mg} / \mathrm{L}, 500 \mathrm{mg} / \mathrm{L}$ concentrations, respectively. Moreover, $S$. aureus, which is one of the strains used in the evaluation of biofilm inhibition activity against NP, was found to be more sensitive than $P$. aeruginosa. In previous studies by different researchers, it has been reported that AgNPs inhibited biofilm formation. Such as; Lara investigated the inhibition effect of AgNPs on biofilm formation of Candida auris after treating silicone elastomer and bandage fibers with silver NP. As a result, they reported that silicone elastomers functionalized with silver NPs demonstrated with $>50 \%$ biofilm inhibition and bandage dressings loaded with silver NPs inhibited growth of $C$. auris biofilms formation by more than $80 \% .{ }^{34}$ In another study, Singh reported that synthesized AgNPs using Cannabis sativa inhibited biofilm formation such bacteria including $P$. aeruginosa and $E$. coli. ${ }^{35}$ The results of this research suggest that the newly synthesized AgNPs using Macrolepiota procera extract could be considered as alternating antimicrobial compounds useful to create new pharmaceutical products.

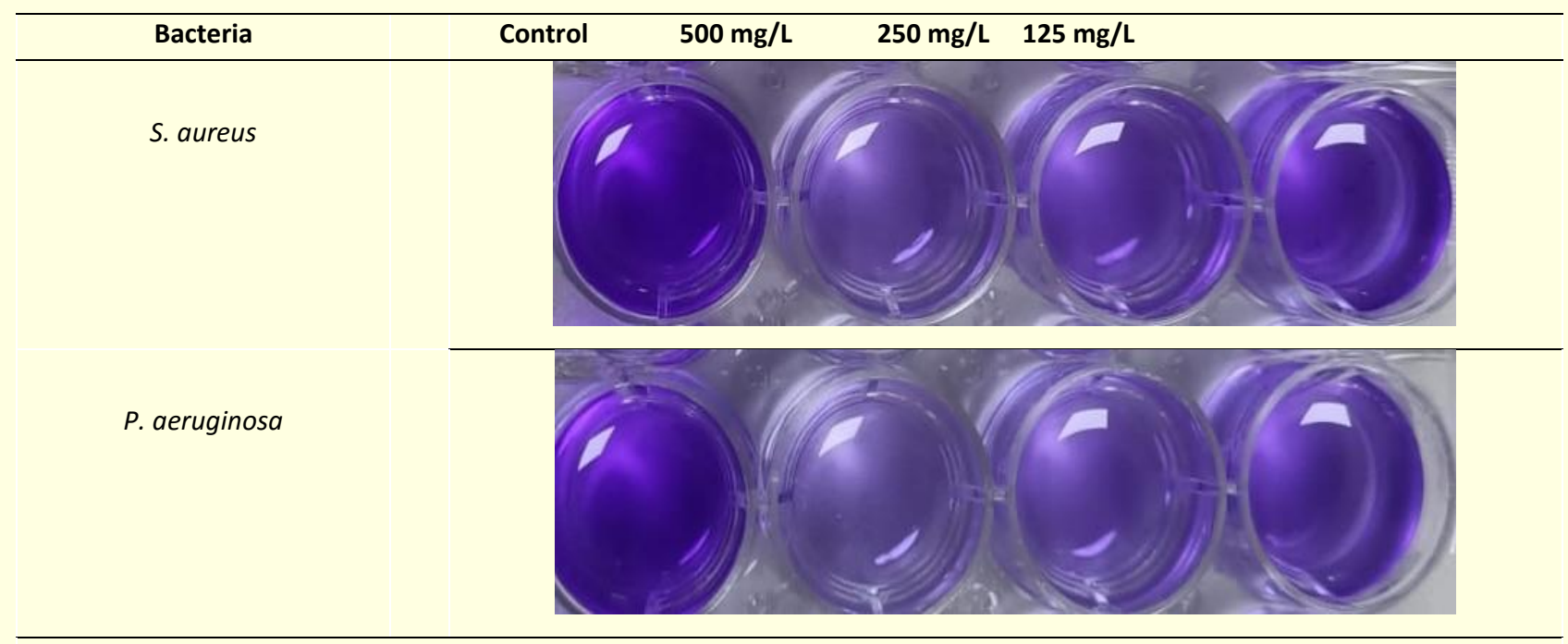

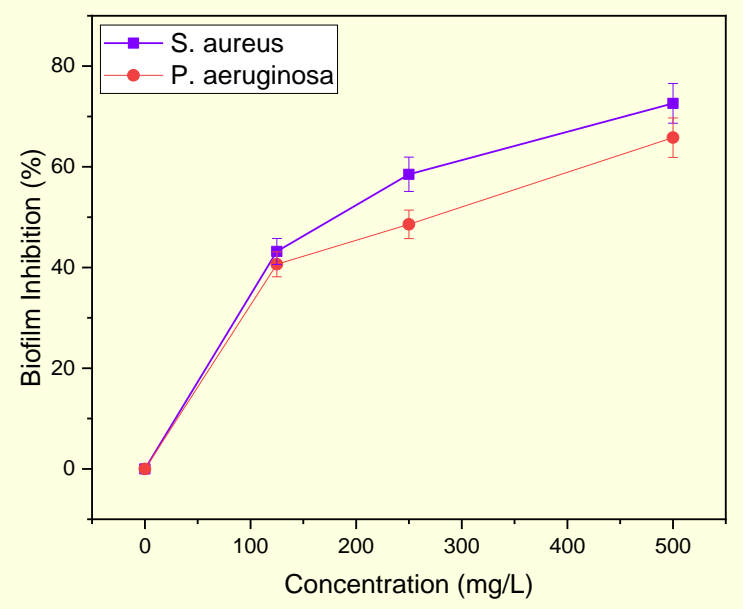

Figure 5. Biofilm Inhibition of $S$. aureus and $P$. aeruginosa 


\section{Conclusion}

Nanotechnology is the most considerable area for developing new medical implementations. The use of Macrolepiota procera for AgNPs synthesis would let for lower toxicity and greater biocompatibility, than those synthesized by other methods (such as chemical methods), which makes them a promising alternative in various applications including bio-indicators, sensing, nanomedicine growth and targeted drug deliver. Moreover, in the potential biological activity of the synthesized AgNPs can be contribute to the presence of the polysaccharides and secondary metabolites the surface of the AgNPs which is present in Macrolepiota procera. The present study is very important as it sheds light upon the in-vitro biological activities of $\mathrm{Mp}$ AgNPs synthesized by the green synthesis method. Moreover, the fact that the synthesized NPs showed good biological activities such as $92.72 \%$ DPPH scavenging activity, biofilm inhibition activity $72.60 \%$ for S.aureus and $65.80 \%$ for $P$. aeruginosa, and showed $99 \%$ cell viability inhibition activity is another important part of the study. According to the present study, it has been determined that the use of Macrolepiota procera is important in the synthesis of silver nanoparticles. As a results, this molecule is promising, further in-vivo examination, pre-clinical and clinical trials are required in this respect.

\section{Acknowledgement}

There is no conflicts of interest. I would like to thank Zelal Işık for their contribution to the study.

\section{References}

1. Kumar Panda M, et al. Green synthesis of silver nanoparticles and its potential effect on phytopathogens. Mater Today Proc 2021;35:233-8.

2. Dhar SA, et al. Plant-mediated green synthesis and characterization of silver nanoparticles using Phyllanthus emblica fruit extract. Mater Today Proc 2021;42:1867-71.

3. Danagoudar A, et al. Characterization, cytotoxic and antioxidant potential of silver nanoparticles biosynthesised using endophytic fungus (Penicillium citrinum CGJ-C1). Mater Today Commun 2020;25(May):101385.

4. Gauthami R, et al. Cissampelous pairera mediated synthesis of silver nanoparticles and it's invitro antioxidant, antibacterial and antidiabetic activities. Mater Today Proc 2020;47(3):853-7.

5. Das G, Patra JK, Shin HS. Biosynthesis, and potential effect of fern mediated biocompatible silver nanoparticles by cytotoxicity, antidiabetic, antioxidant and antibacterial, studies. Mater Sci Eng C 2020;114(June 2019):111011.

6. Mousavi SAA, Salari S, Hadizadeh S. Evaluation of antifungal effect of silver nanoparticles against microsporum canis, trichophyton mentagrophytes and microsporum gypseum. Iran J Biotechnol 2015;13(4).

7. Hashemi SF, Tasharrofi N, Saber MM. Green synthesis of silver nanoparticles using Teucrium polium leaf extract and assessment of their antitumor effects against MNK45 human gastric cancer cell line. J Mol Struct 2020;1208.

8. Ozlem Saygi K, Usta C. Rosa canina waste seed extract-mediated synthesis of silver nanoparticles and the evaluation of its antimutagenic action in Salmonella typhimurium. Mater Chem Phys 2021;266(March):124537.

9. Sreekanth TVM, et al. Ultra-sonication-assisted silver nanoparticles using Panax ginseng root extract and their anti-cancer and antiviral activities. J Photochem Photobiol B Biol 2018;188:6-11.

10. Chavan RR, et al. Characterization, antioxidant, antimicrobial and cytotoxic activities of green synthesized silver and iron nanoparticles using alcoholic Blumea eriantha DC plant extract. Mater Today Commun 2020;24(May):101320.

11. Ahn EY, Jin H, Park Y. Assessing the antioxidant, cytotoxic, apoptotic and wound healing properties of silver nanoparticles greensynthesized by plant extracts. Mater Sci Eng C 2019;101(March):204-16.

12. Krupodorova T, Sevindik M. Antioxidant potential and some mineral contents of wild edible mushroom Ramaria stricta. AgroLife Sci J 2020;9(1):186-91.

13. Ayeka PA. Potential of Mushroom Compounds as Immunomodulators in Cancer Immunotherapy: A Review. Evidence-based Complement Altern Med 2018; 7271509.1-9.

14. Aydın E et al. Effect of Different Processing Technologies on chemical Properties of Wild-Grown Edible mushroom Macrolepiota Procera Var.Procera (Scop.). Journal of Food Processing and Preservation 2017; 41:e12802.

15. Kosanić $\mathrm{M}$, et al. Evaluation of metal concentration and antioxidant, antimicrobial, and anticancer potentials of two edible mushrooms Lactarius deliciosus and Macrolepiota procera. J Food Drug Anal 2016;24(3):477-84.

16. Sabir S, et al. Biosynthesis of ZnO Nanoparticles Using Bacillus Subtilis: Characterization and Nutritive Significance for Promoting Plant Growth in Zea mays L, Dose-Response: An International Journal 2020:1-9. 
17. Agırtaş MS, Karatas C, Özdemir S. Synthesis of some metallophthalocyanines with dimethyl 5- (phenoxy)-isophthalate substituents and evaluation of their antioxidant-antibacterial activities. Spectrochimica Acta Part A : Molecular and Biomolecular Spectroscopy 2015;135:20-4.

18. Alsubki R, et al. Green synthesis, characterization, enhanced functionality and biological evaluation of silver nanoparticles based on Coriander sativum. Saudi J Biol Sci 2021;28(4):2102-8.

19. Chick CN, et al. Preparation and antioxidant study of silver nanoparticles of Microsorum pteropus methanol extract. Bioorganic Med Chem Lett 2020;30(22):127526.

20. Odeniyi MA, et al. Green synthesis and cream formulations of silver nanoparticles of Nauclea latifolia (African peach) fruit extracts and evaluation of antimicrobial and antioxidant activities. Sustain Chem Pharm 2020;15(November 2019).

21. Maheshwaran G, et al. Green synthesis of Silver oxide nanoparticles using Zephyranthes Rosea flower extract and evaluation of biological activities. J Environ Chem Eng 2020;8(5):104137.

22. Palanisamy S, et al. Green route to synthesis silver nanoparticles using Sargassum polycystum and its antioxidant and cytotoxic effects: An in vitro analysis. Mater Lett 2017;189:196-200.

23. Ravichandran V, et al. Green synthesis of silver nanoparticles using Atrocarpus altilis leaf extract and the study of their Antimicrobial and antioxidant activity, Mater Lett 180 (2016) 264-267.

24. Wang L, et al. Characterization, antioxidant and antimicrobial activities of green synthesized silver nanoparticles from Psidium guajava L. leaf aqueous extracts. Mater Sci Eng C 2018;86(April 2017):1-8.

25. Khorrami S, Zarepour A, Zarrabi A. Green synthesis of silver nanoparticles at low temperature in a fast pace with unique DPPH radical scavenging and selective cytotoxicity against MCF-7 and BT-20 tumor cell lines. Biotechnol Reports 2019;24:e00393.

26. Mousavi-Khattat M, Keyhanfar M, Razmjou A. A comparative study of stability, antioxidant, DNA cleavage and antibacterial activities of green and chemically synthesized silver nanoparticles. Artif Cells, Nanomedicine Biotechnol 2018; 46 (sup3):S1022-31.

27. Begum MY, Alhamhoom Y, Roy A. Study of antimicrobial and DNA cleavage property of biocompatible silver nanoparticles prepared by using Ficus carica L. Mater Res Innov 2021;25(3):147-54.

28. Morales-Lozoya V, et al. Study of the effect of the different parts of Morinda citrifolia L. (noni) on the green synthesis of silver nanoparticles and their antibacterial activity. Appl Surf Sci 2021;537(February 2020):147855.

29. Alsubki R, et al. Green synthesis, characterization, enhanced functionality and biological evaluation of silver nanoparticles based on Coriander sativum. Saudi J Biol Sci 2021;28(4):2102-8.

30. Sathishkumar RS, et al. Green synthesis of silver nanoparticles by bloom forming marine microalgae Trichodesmium erythraeum and its applications in antioxidant, drug-resistant bacteria, and cytotoxicity activity. J Saudi Chem Soc 2019;23(8):1180-91.

31. Sangaonkar GM, Pawar KD. Garcinia indica mediated biogenic synthesis of silver nanoparticles with antibacterial and antioxidant activities. Colloids Surfaces B Biointerfaces 2018;164:210-7.

32. Mehwish HM, et al. Green synthesis of a silver nanoparticle using Moringa oleifera seed and its applications for antimicrobial and sun-light mediated photocatalytic water detoxification. J Environ Chem Eng 2021;9(4):105290.

33. Jalilian F, et al. Green synthesized silver nanoparticle from Allium ampeloprasum aqueous extract: Characterization, antioxidant activities, antibacterial and cytotoxicity effects. Adv Powder Technol 2020;31(3):1323-32.

34. Lara HH, et al. Inhibition of Candida auris Biofilm Formation on Medical and Environmental Surfaces by Silver Nanoparticles. ACS Appl Mater Interfaces 2020;12(19):21183-91.

35. Singh P, et al. green synthesis of gold and silver nanoparticles from Cannabis sativa (industrial hemp) and their capacity for biofilm inhibition. Int J Nanomedicine 2018;13:3571-91. 